\title{
Association between body composition and aerobic capacity in karate athletes
}

\section{Associação entre composição corporal e capacidade aeróbica em atletas de karate}

\author{
José Francisco da Silva ${ }^{1}$ \\ (1D) https://orcid.org/0000-0003-0934-9826 \\ Javiera Alarcón Aguilar ${ }^{1}$ \\ (D) https://orcid.org/0000-0003-4267-046X \\ Carlos Alberto Morena Moya ${ }^{1}$ \\ (D) https://orcid.org/0000-0002-7127-0855 \\ Murilo Gominho Antunes Correia Junior \\ (D) https://orcid.org/0000-0002-2395-2210 \\ Willemax dos Santos Gomes 2 \\ (D) https://orcid.org/0000-0002-3498-9959 \\ Valéria Mayaly Alves de Oliveira ${ }^{3}$ \\ (D) https://orcid.org/0000-0001-8562-483X \\ Marcos André Moura dos Santos ${ }^{1}$ \\ (D) https://orcid.org/0000-0002-2734-8416 \\ Daniel da Rocha Queiroz ${ }^{1}$ \\ (D) https://orcid.org/0000-0002-9901-4677
}

Abstract -The aim of this study was to analyze the association between body composition and performance in the karate specific aerobic test (KSAT). This is a study carried out with thirteen athletes ( 6 females) with a mean age of $20.7 \pm 4.2$ years, affiliated to the Pernambuco Federation of Karate Associations, were developing this training routine during the 2018 season. Body mass and height were measured. To measure body composition, the body densitometry method was used by the x-ray double-ray absorptiometry (DEXA) technique. Karate Specific Aerobic Test was used to verify aerobic performance. Association analyzes were performed between body composition variables and KSAT performance using Pearson's correlation test and linear regression. All analyzes adopted a significance of $\mathrm{p}<0.05$. KSAT performance was negatively correlated with total fat mass $(\mathrm{r}=-0.797 ; \mathrm{p}=0.001)$ and fat percentage $(\mathrm{r}=-0.757$; $p=0.003$ ). The linear regression model with the highest explanatory power included total fat and KSAT (adjusted $\mathrm{R}^{2}=0.732 ; \mathrm{p}<0.001$ ) exhibited a negative association with total fat $(\beta$ $=-0.21 ; \mathrm{p}<0.001$ ), and the model that included $\%$ body fat and KSAT (adjusted $\mathrm{R}^{2}=0.708$; $\mathrm{p}=0.003)$ were negatively associated with $\%$ body fat $(\beta=-22.937 ; \mathrm{p}=0.001)$, both adjusted for gender and age. There is a negative association between total fat mass, body fat percentage and karate specific aerobic test performance.

Key words: Athletic performance; Body composition; Martial arts.

\footnotetext{
Resumo - Objetivou-se analisar a associação entre composição corporal e desempenho no teste aeróbico especifico do karatê (KSAT). Trata-se de um estudo realizado com treze atletas (6 mulheres) com idade média de 20,7 44,2 anos, afiliados à Federação das Associações de Karatê de Pernambuco, estavam desenvolvendo essa rotina de treinamento durante a temporada de 2018. A massa corporal e a estatura foram medidas. Para medir a composição corporal, o método de densitometria corporal foi utilizado pela técnica de absorciometria por raios- $x$ duplos (DEXA). Teste aeróbico específico de karatê foi usado para verificar o desempenho aeróbico. As análises de associação foram realizadas entre as variáveis de composição corporal e o desempenho do KSAT usando o teste de correlação de Pearson e regressão linear. Todas as análises adotaram uma significância de $p<0,05$. O desempenho no KSAT foi negativamente correlacionado com a massa gorda total $(r=-0,797 ; p=0,001)$ e o percentual de gordura $(r=-0,757 ; p=0,003)$. O modelo de regressão linear com maior poder explicativo incluiu gordura total e $K S A T\left(R^{2}\right.$ ajustado $\left.=0,732 ; p<0,001\right)$ exibiu associação negativa com gordura total $(\beta=-0,21 ; p<0,001)$ e o modelo que incluiu\% de gordura corporal e $K S A T\left(R^{2}\right.$ ajustado $=0,708 ; p$ $=0,003)$ foram associados negativamente com\% de gordura corporal $(\beta=-22,937 ; p=0,001)$, ambos ajustados por sexo e idade. Existe uma associação negativa entre a massa gorda total, o percentual de gordura corporal e o desempenho aeróbico especifico do karatê.
}

Palavras-chave: Artes marciais; Composição corporal; Desempenho atlético.
1 Universidade de Pernambuco. Escola Superior de Educação Física. Recife, PE. Brasil

2 Universidade Federal de Pernambuco. Departamento de Educação Física. Recife, PE. Brasil

3 Centro Universitário Vale do Ipojuca. Colegiado de Fisioterapia. Caruaru, PE. Brasil.

Received: March 03, 2020 Accepted: April 11, 2020

How to cite this article Silva JF, Aguilar JA, Moya CAM, Correia Junior MGA, Gomes WS, Oliveira VMA, Santos MAM, Queiroz DR. Association between body composition and aerobic capacity in karate athletes. Rev Bras Cineantropom Desempenho Hum 2020, 22:e71989. Dol: http://dx.doi. org/10.1590/1980-0037.2020v22e71989

Copyright: This work is licensed under a Creative Commons Attribution 4.0 International License. 


\section{INTRODUCTION}

In most combat sports, there is no single dominant feature in performance, however the set of actions formed by technique, strength, aerobic capacity, muscle power and speed is the most required during competitions. The physiological characteristics of these athletes are usually measured by testing their physical fitness components (cardiorespiratory endurance, muscle strength, muscle endurance, flexibility and body composition) and sports performance (speed, agility, power, balance, coordination and reaction time $)^{1,2}$. Some studies have reported that lean body mass has a positive relationship with performance, especially in sports that require great application of force, in which their athletes have a large amount of lean mass and a low percentage of body fat ${ }^{3-5}$.

Karate is divided into Kata (pre-established moves and sequences of offensive and defensive techniques) and Kumite (combat between two competitors, in which they are free to move, kick and punch defensively and offensively), currently one of the most engaging combat sports, a fact confirmed by the millions of people who practice karate around the world ${ }^{6}$. Kumite competitions are three-minute long and use vigorous action through external loads, agile and powerful moves, with one execution intermittent steps for effective acts of attack and defense. In this sport of combat, practitioners are required to have a high technical ability, with the control of movement in static and dynamic conditions, and the execution of techniques (punches and kicks) in ballistic actions ${ }^{6-10}$.

Among karate fighters, the morphological characteristics are extremely important, as they can provide specific details about the morphology and functional biotype most suitable for this sport ${ }^{10}$. In sporting competitions with well-defined weight categories such as karate, weight gain due to fat accumulation can drastically influence an athlete's ability to perform well ${ }^{11}$. Thus, the assessment of karatekas body composition requires special attention. High-level male athletes are characterized by low body fat and mesomorphic or ectomorphic somatotypic characteristics; however, studies addressing the body composition and somatotype of female practitioners are scarce $^{10}$. Regarding the metabolic dimension, studies have highlighted the important role of aerobic capacity in karate, such as the ability to prevent fatigue during training and combat, ensuring recovery processes during rest periods. Explosive actions, it has been well established that in the general metabolic profile of karateka, the aerobic energy pathway is predominant with no significant difference in performance between genders ${ }^{10,12-14}$.

Nunan ${ }^{14}$, proposed a specific test for the assessment of aerobic fitness in karateka, called the Karate Specific Aerobic Test (KSAT). This protocol is considered reproducible and has good levels of test and retest reliability ${ }^{15}$. In addition, it is easy to apply, requiring materials present in any karate training academy. In 2014, Tabben et al. ${ }^{16}$ developed a new KSAT, making the specifics of fighting more reliable, this new version was considered valid, reliable and had a good discriminating capacity of aerobic 
performance, with no significant difference between $\mathrm{VO}_{2}$ peak measured from KSAT and $\mathrm{VO}_{2}$ max registered in the laboratory cycle ergometer test. Therefore, KSAT can be considered as the most appropriate field-specific test for karateka aerobic fitness assessment and monitoring. But despite this, and the relevance of the body composition analysis of the karateka, to our knowledge, there are no studies that made any association between indicators of body composition and performance of athletes in KSAT. Thus, this study aims to analyze the association between body composition and performance in the Karate Specific Aerobic Test.

\section{METHOD}

\section{Study design and sample}

This cross-sectional, descriptive, and correlation study. Ethical approval was obtained from the Institutional Ethics Board [University of Pernambuco, Recife-PE (CAAE-02789018.5.0000.5192)], and the protocol was written in accordance with the standards established by the Declaration of Helsinki. All athletes had their informed consent signed. Thirteen junior, under-21 and senior athletes with a mean age of $20.7 \pm 4.2$ years, affiliated to the Pernambuco Federation of Karate Associations (FPAK), who were developing in this study, were included. the training routine during the 2018 season and competed in the special category (purple to black belt).

\section{Instruments and Procedures}

To determine the level of aerobic fitness, an indirect method that most closely approximates the physiological specificity of this sport was used, the Karate Specific Aerobic Test (KSAT), which is composed of a repeated sequential set of punches and kicks (Kizame-Guiaku tsuki and Mawashi geri), performed at a maximum power of 3 seconds, respectively, in a specific bag, properly fixed at a minimum distance of 1 meter, demarcated on the ground, which the athlete was positioned behind waiting for the start of the test and returning to its starting position after the sequence, to perform active pauses with steps. The progression of this test occurs by increasing the intensity by reducing the active recovery periods between exercises, according to the levels and stages proposed by the test protocol. The start and end of these punch, kick and active pause sequences are notified by beeps. The test ends when an athlete cannot perform the set of strokes within 3 seconds, or when an experienced appraiser (Karate referee, coach or black belt) identifies that the strokes are not being performed at their maximum power ${ }^{16}$. The beeps (Beeps) were emitted by a sound amplifier, connected to a computer, through a program created in $\mathrm{C}++$ language in Code Blocks 16.0 software for Windows, which besides the sound emission in their respective teams, showed the levels, stages and the time elapsed from the start of the test in seconds. All were instructed on the test protocol and conducted a warm-up with movements similar to those of the KSAT, with self-selected intensity for 5 minutes, followed by a passive rest of the same 
duration, immediately after starting the test. All were verbally encouraged throughout the test and it was interrupted when the athlete was unable to perform the set of strokes within the timeframe provided for in the protocol or when an experienced evaluator (in our study was evaluated by a referee from the National Confederation of Karate - CBK) identified that the blows were not being executed at their maximum power.

Body mass and height were measured using a digital stadiometer (WELMY ${ }^{\circledR} 2012$, Brazil) with a maximum load of $200 \mathrm{~kg}$ and a precision of $0.05 \mathrm{~kg}$ and a maximum height of $200 \mathrm{~cm}$ with a precision of $0.05 \mathrm{~cm}$, respectively. Based on these measurements the body mass index was calculated $\left[\mathrm{kg} /(\mathrm{m})^{2}\right]$. This procedure was performed by a single evaluator following the recommendations described by the International Society for Advancement in Kinanthropometry ${ }^{17}$. To measure body composition (total fat free mass, lower limbs, trunk, total fat mass and fat percentage), the body densitometry method was used by the x-ray double-ray absorptiometry (DEXA) technique, with the equipment of model HOLOGIC QDR WI. All were examined in the morning, remained in the supine position with hip reversion, wearing light clothes and without metal parts during the scanner, for about 6 minutes, according to the recommendations provided in the evaluation protocol ${ }^{18}$.

\section{Statistical analysis}

Data normality was assessed by the Shapiro-Wilk test. Data were presented in a descriptive table with mean, standard deviation, minimum and maximum values according to gender. Pearson's moment-product correlation was used to verify the relationship between body composition and specific aerobic performance. Linear regression was performed to assess the association between body composition indicators (\% fat and total fat in grams) and KSAT performance, adjusted for gender and age. It was using the Enter input method to include the variables in the model. Sex and age were considered confounders. The variance inflation factor (VIF $<5)$ was used as an indicator of the absence of multicollinearity. All analyzes were performed using the SPSS 20.0 statistical package, adopting a significance level of $\mathrm{p}<0.05$.

\section{RESULTS}

Table 1 presents the descriptive characteristics of the athletes with mean, standard deviation, minimum and maximum, anthropometric indicators, body composition and KSAT performance.

Table 2 shows the correlations between KSAT performance, anthropometric and body composition indicators. It was observed that KSAT performance showed negative and significant correlations with total fat mass $(r=-0.797 ; p=0.001)$ and fat percentage $(r=-0.757 ; p=0.003)$.

Tables 3 and 4 show the linear regression analyzes. The model with the highest explanatory power included total fat and KSAT (adjusted $\mathrm{R}^{2}$ 
$=0.732 ; \mathrm{p}<0.001)$ showing a negative association with total fat $(\beta=-0.21$; $\mathrm{p}<0.001$ ) followed by the model that included $\%$ fat and KSAT (adjusted $\left.\mathrm{R}^{2}=0.708 ; \mathrm{p}=0.003\right)$ showing a negative association with $\%$ body fat $(\beta$ $=-22.937 ; \mathrm{p}=0.001)$, both adjusted for sex and age.

Table 1. Descriptive characteristics of the sample (mean, standard deviation, minimum and maximum) of anthropometric indicators, body composition and performance in Karate Specific Aerobic Test.

\begin{tabular}{|c|c|c|c|c|c|c|}
\hline \multirow[b]{2}{*}{ Variables } & \multicolumn{2}{|c|}{ Male } & \multicolumn{2}{|c|}{ Female } & \multicolumn{2}{|c|}{ Total } \\
\hline & $\begin{array}{l}\text { Mean } \pm \text { SD } \\
(n=7)\end{array}$ & Min-Max & $\begin{array}{l}\text { Mean } \pm S D \\
\quad(n=6)\end{array}$ & Min-Max & $\begin{array}{c}\text { Mean } \pm \text { SD } \\
(n=13)\end{array}$ & Min-Max \\
\hline Age (years) & $20,00(4,43)$ & $16-29$ & $21,50(4,13)$, & $18-28$ & $20,69(4,19)$ & $16-29$ \\
\hline \multicolumn{7}{|c|}{ Anthropometry and Body Composition } \\
\hline Body Mass (Kg) & $77,14(14,87)$ & $63-104$ & $58,53(7,359)$ & $50-68$ & $68,55(15,04)$ & $50-104$ \\
\hline Height (cm) & $175,23(9,62)$ & $164-191$ & $161,85(5,05)$ & $154-167$ & $169,05(10,25)$ & $154-191$ \\
\hline BMI $\left(\mathrm{Kg} / \mathrm{m}^{-2}\right)$ & $24,99(3,30)$ & $21,81-30,11$ & $22,38(3,01)$ & $18,69-27,06$ & $23,79(3,32)$ & $18,69-30,11$ \\
\hline Lean Fat mass - Lower limbs (Kg) & $19,95(2,83)$ & $16,27-25,03$ & $13,53(2,07)$ & $11,25-15,69$ & $16,99(4,11)$ & $11,25-25,03$ \\
\hline $\begin{array}{l}\text { Lean Fat mass - Lower limbs } \\
\text { and trunk }(\mathrm{Kg})\end{array}$ & $47,08(6,19)$ & $40,83-58,97$ & $30,03(7,74)$ & $16,92-38,32$ & $39,21(11,06)$ & $16,92-58,97$ \\
\hline Lean Fat mass - Total (Kg) & $53,09(15,99)$ & $19,69-70,88$ & $39,58(4,94)$ & $34,15-46,09$ & $46,85(13,68)$ & $19,69-70,88$ \\
\hline Fat mass $(\mathrm{Kg})$ & $15,44(7,87)$ & $8,13-27,55$ & $15,78(3,28)$ & $12,02-21,64$ & $67,35(14,84)$ & $8,13-27,55$ \\
\hline Fat percentage (\%) & $19,46(6,49)$ & $12-27$ & $27,33(3,34)$ & $23-32$ & $23,09(6,51)$ & $12-32$ \\
\hline \multicolumn{7}{|l|}{ Performance } \\
\hline Karate Specific Aerobic Test (s) & $438,43(178,04)$ & $210-667$ & $329,83(50,95)$ & $270-385$ & $388,31(141,79)$ & $210-667$ \\
\hline
\end{tabular}

Note. $\mathrm{SD}=$ Standard desviation; BMI=Body mass index.

Table 2. Correlations between Body Composition and performance in Karate Specific Aerobic Test.

\begin{tabular}{|c|c|c|c|c|c|c|c|c|c|}
\hline Variables & $\begin{array}{c}\text { Karatê } \\
\text { Specific } \\
\text { Aerobic } \\
\text { Test (s) }\end{array}$ & $\begin{array}{l}\text { Body } \\
\text { Mass } \\
(\mathrm{Kg})\end{array}$ & $\begin{array}{l}\text { Height } \\
(\mathrm{cm})\end{array}$ & $\begin{array}{c}\mathrm{BMI} \\
\left(\mathrm{Kg} \cdot \mathrm{m}^{-2}\right)\end{array}$ & $\begin{array}{l}\text { Lean Fat } \\
\text { mass - } \\
\text { Lower } \\
\text { limbs }(g)\end{array}$ & $\begin{array}{l}\text { Lean Fat } \\
\text { mass - } \\
\text { Lower limbs } \\
\text { and trunk(g) }\end{array}$ & $\begin{array}{c}\text { Lean Fat } \\
\text { mass - } \\
\text { Total }(\mathrm{g})\end{array}$ & $\begin{array}{l}\text { Fat mass } \\
\text { - Total } \\
\text { (g) }\end{array}$ & $\begin{array}{c}\text { Fat } \\
\text { percentage } \\
(\%)\end{array}$ \\
\hline $\begin{array}{l}\text { Karatê Specific Aerobic } \\
\text { Test (s) }\end{array}$ & $(-)$ & & & & & & & & \\
\hline Body Mass (Kg) & $\begin{array}{l}-0,242 \\
(0,426)\end{array}$ & $(-)$ & & & & & & & \\
\hline Height (cm) & $\begin{array}{c}0,264 \\
(0,384)\end{array}$ & $\begin{array}{l}0,582^{*} \\
(\mathbf{0 , 0 3 7 )}\end{array}$ & $(-)$ & & & & & & \\
\hline $\mathrm{BMI}\left(\mathrm{Kg} \cdot \mathrm{m}^{-2}\right)$ & $\begin{array}{l}-0,511 \\
(0,074)\end{array}$ & $\begin{array}{l}0,786^{\star *} \\
(\mathbf{0}, \mathbf{0 0 1})\end{array}$ & $\begin{array}{c}0,044 \\
(0,887)\end{array}$ & $(-)$ & & & & & \\
\hline $\begin{array}{l}\text { Lean Fat mass - Lower } \\
\text { limbs }(\mathrm{g})\end{array}$ & $\begin{array}{l}0,0000 \\
(1,000)\end{array}$ & $\begin{array}{l}0,923^{* *} \\
(\mathbf{0}, \mathbf{0 0 0})\end{array}$ & $\begin{array}{l}0,599^{*} \\
(\mathbf{0}, \mathbf{0 3 1})\end{array}$ & $\begin{array}{l}0,687^{\star \star} \\
(\mathbf{0}, \mathbf{0 1 0})\end{array}$ & $(-)$ & & & & \\
\hline $\begin{array}{l}\text { Lean Fat mass - Lower } \\
\text { limbs and trunk (g) }\end{array}$ & $\begin{array}{l}-0,038 \\
(0,901)\end{array}$ & $\begin{array}{l}0,890^{* *} \\
(\mathbf{0}, \mathbf{0 0 0})\end{array}$ & $\begin{array}{l}0,665^{*} \\
(\mathbf{0}, \mathbf{0 1 3})\end{array}$ & $\begin{array}{c}0,615 \\
(0,025)\end{array}$ & $\begin{array}{l}0,945^{\star *} \\
(\mathbf{0}, \mathbf{0 0 0})\end{array}$ & $(-)$ & & & \\
\hline $\begin{array}{l}\text { Lean Fat mass - Total } \\
(\mathrm{kg})\end{array}$ & $\begin{array}{l}-0,181 \\
(0,553)\end{array}$ & $\begin{array}{l}0,830^{* *} \\
(\mathbf{0}, \mathbf{0 0 0})\end{array}$ & $\begin{array}{c}0,467 \\
(\mathbf{0 , 1 0 8 )}\end{array}$ & $\begin{array}{l}0,747^{* *} \\
(\mathbf{0}, \mathbf{0 0 3})\end{array}$ & $\begin{array}{l}0,863^{* *} \\
(\mathbf{0}, \mathbf{0 0 0})\end{array}$ & $\begin{array}{l}0,852^{\star *} \\
(0,000)\end{array}$ & $(-)$ & & \\
\hline Fat mass - Total (kg) & $\begin{array}{l}-0,797^{* *} \\
(\mathbf{0}, \mathbf{0 0 1})\end{array}$ & $\begin{array}{c}0,473 \\
(0,103)\end{array}$ & $\begin{array}{c}0,005 \\
(0,986)\end{array}$ & $\begin{array}{l}0,698^{* *} \\
(0,008)\end{array}$ & $\begin{array}{c}0,220 \\
(\mathbf{0 , 4 7 1 )}\end{array}$ & $\begin{array}{l}0,209 \\
(0,494)\end{array}$ & $\begin{array}{c}0,341 \\
(0,255)\end{array}$ & $(-)$ & \\
\hline Fat percentage (\%) & $\begin{array}{c}-0,757^{* *} \\
(0,003)\end{array}$ & $\begin{array}{l}-0,149 \\
(0,628)\end{array}$ & $\begin{array}{l}-0,481 \\
(0,096)\end{array}$ & $\begin{array}{c}0,226 \\
(0,459)\end{array}$ & $\begin{array}{l}-0,429 \\
(0,143)\end{array}$ & $\begin{array}{l}-0,410 \\
(0,164)\end{array}$ & $\begin{array}{l}-0,234 \\
(0,442)\end{array}$ & $\begin{array}{l}0,707^{\star *} \\
(\mathbf{0}, \mathbf{0 0 7})\end{array}$ & $(-)$ \\
\hline
\end{tabular}

Note. ${ }^{*} \leq \leq 0.05 ;{ }^{* \star} \mathrm{p} \leq 0.01 ; \mathrm{BMI}=$ Body mass index 
Table 3. Association between body fat percentage and aerobic performance

\begin{tabular}{lcccccc}
\hline & & \multicolumn{3}{c}{ Unadjusted $(\mathrm{n}=13)$} & \multicolumn{2}{c}{ Model I $(\mathrm{n}=13)$} \\
\cline { 3 - 7 } & & SE & $\mathrm{p}$ & $\mathrm{b}$ & $\mathrm{SE}$ & $\mathrm{p}$ \\
\hline Body Fat (\%) & -18.396 & 3.503 & $<0.001$ & -22.937 & 4.530 & 0.001 \\
Sex (Female) & -108.595 & 75.613 & 0.179 & 61.651 & 54.700 & 0.289 \\
Age (years) & -3.339 & 10.152 & 0.748 & 6.939 & 5.584 & 0.245 \\
(Constant) & - & - & - & 684.288 & 121.474 & $<0.001$ \\
\hline
\end{tabular}

Note. $\mathrm{R}^{2}$ adjusted $=0.708 ; \mathrm{SE}=$ Standard error.

Table 4. Association between total body fat and aerobic performance

\begin{tabular}{lcccccc}
\hline & & \multicolumn{3}{c}{ Unadjusted $(\mathrm{n}=13)$} & \multicolumn{2}{c}{ Model I $(\mathrm{n}=13)$} \\
\cline { 3 - 7 } & & SE & $\mathrm{p}$ & $\mathrm{b}$ & $\mathrm{SE}$ & $\mathrm{p}$ \\
\hline Body Fat $(\mathrm{g})$ & -0.018 & 0.005 & 0.004 & -0.21 & 0.004 & $<0.001$ \\
Sex (Female) & -108.595 & 75.613 & 0.179 & -120.210 & 41.59 & 0.018 \\
Age (years) & -3.339 & 10.152 & 0.748 & 12.538 & 5.718 & 0.056 \\
(Constant) & - & - & - & 635.327 & 114.890 & $<0.001$ \\
\hline
\end{tabular}

Note. $R^{2}$ adjusted $=0.732 ; S E=S t a n d a r d$ error

\section{DISCUSSION}

The aim of this study was to analyze the association between body composition and performance in the Karate Specific Aerobic Test (KSAT). Our study hypothesis determined that there would be a negative association between body composition indicators and KSAT performance. One of the main results presented was that KSAT performance presented negative and significant associations with total fat mass and fat percentage, with determination coefficients higher than 0.70 . Regarding the association values, the higher the value of the composition indicators, the lower the aerobic performance of the athlete in the test. Linear regression analysis showed that with the increase of 1 gram of fat the aerobic performance decreased by 0.21 seconds and with the increase of $1 \%$ body fat the decrease was 22 seconds. Although the model that included an absolute measurement (fat mass in grams) was statistically more significant, the model with relative measurement $(\% \mathrm{G})$ has greater applicability in the practical environment.

Sex and age are variables settings, as they may influence the variables of interest (body composition and aerobic performance). For physiology, the reference man is taller, heavier, has greater muscle mass, lower body fat content and a higher respiratory capacity when compared to the reference woman. This model is considered useful and is widely used for statistical comparisons and interpretations of data from studies of elite athletes, individuals involved in physical training, different racial and ethnic groups. Moreover, these variables suffer negative influences related to their role in performance with advancing age ${ }^{19}$.

Assessing the aerobic capacity of karate athletes is of paramount importance, as according to some studies, this metabolism is predominant during combat ${ }^{10,12-14}$. In addition, it may play an important role in preventing fatigue 
during training, within a fight, during the rest period between subsequent matches ${ }^{10}$. Therefore, identifying the level of aerobic fitness is crucial to check if the athlete is able to achieve good performance and to promote the development of this component in the training program. Although some studies show that there are no significant differences between athletes of different competitive levels, beginners and veterans, regarding body composition and neuromotor variables $\mathrm{s}^{3,10,20}$. This study included only special category athletes (purple belt or higher), because they represent the "professional" category of this sport, besides representing the most prepared athletes of the state federation.

Because karate athletes are divided into weight categories, it is a common approach to try to maximize lean body mass and reduce body fat to compete in the underweight category and increase the likelihood of success $^{21}$. Despite the relevance of body mass control to karate competitors, only a few studies have attempted to verify the differences between athletes of different competitive levels in relation to body fat percentage, however, they did not find significant differences ${ }^{11,22}$. A possible explanation for these results may be the fact that elite karate athletes have low body fat percentage and therefore no difference is detectable between the different levels ${ }^{21}$. This study also corroborates this statement; however, the athletes had a fat percentage considered high when compared to other studies with elite athletes. Studies relating the success rate to $\% \mathrm{G}$ in karate competitions also found no significant differences ${ }^{7}$. Thus, we could assume that body fat does not appear to be a performance determinant, specifically the quantitative measure of the number of wins in wrestling matches. However, in the present study, relative or absolute body fat mass had a negative influence on KSAT performance, implying that this variable could influence athletes' performance during combat, adding information that differs from that found in the scientific literature.

The present study has some limitations. The use of a cross-sectional design precludes the identification of causality, the knowledge of changes that occur throughout the season, the effect of training and nutritional control on these characteristics. However, the evaluations were performed in all athletes in the same competitive period, exposing all the same conditions. Future studies should seek answers to some of the questions posed here as limitations and evaluate other physical, functional, and nutritional parameters in elite Brazilian karate athletes.

As positive aspects we highlight the evaluation of elite athletes, who represent this state in national and international competitions, which denotes its importance for the production of knowledge in high level Brazilian karate. Another positive aspect was the use of the body densitometry method through the $\mathrm{x}$-ray double-beam absorptiometry (DEXA) technique, which is widely used to perform body composition measurement, specifically the total $\% \mathrm{G}$, bringing more accurate results. Our study used a software, which was developed to show the time traveled (in seconds), the levels and stages reached and to emit the Karate Specific Aerobic Test beeps, thus making possible failures in the moments of the emission of the beeps in due time. 


\section{CONCLUSION}

There is a negative association between total fat mass, body fat percentage and Karate Specific Aerobic Test performance. KSAT performance was higher in athletes with lower total fat mass and lower fat percentage.

\section{COMPLIANCE WITH ETHICAL STANDARDS}

\section{Funding}

This research did not receive any specific grant from funding agencies in the public, commercial, or not-for-profit sectors. This study was funded by the authors.

\section{Ethical approval}

Ethical approval was obtained from the Institutional Ethics Board [University of Pernambuco, Recife-PE (CAAE-02789018.5.0000.5192)], and the protocol was written in accordance with the standards established by the Declaration of Helsinki.

\section{Conflict of interest statement}

The authors declare that they have no competing interests.

\section{Authors Contributions}

Conception and design of the experiment: JFS; MAMS; DRQ. Realization of the experiments: JFS; JAA; CAMM; MGACJ; WSG; VMAO; DRQ. Data analysis: JFS; DRQ. Contribution with reagents/research materials/analysis tools: VMAO; MAMS; DRQ. Article Writing: JFS; JAA; CAMM; MGACJ; WSG; DRQ. All authors read and approved the final version of the manuscript.

\section{REFERENCES}

1. Beekley MD, Abe T, Kondo M, Midorikawa T, Yamauchi T. Comparison of normalized maximum aerobic capacity and body composition of sumo wrestlers to athletes in combat and other sports. J Sports Sci Med 2006;5(CSSI):13-20.

2. Vanhees L, Lefevre J, Philippaerts R, Martens M, Huygens W, Troosters T, et al. How to assess physical activity? How to assess physical fitness? Eur J Cardiovasc Prev Rehabil 2005;12(2):102-14.

3. Boileau RA, Horswill CA. Body composition in sports: Measurement and applications for weight loss and gain. Exerc Sport Sci 2000:319-38.

4. Bertini I, Pujia A, Giampietro M. A follow-up study of the variations in the body composition of karate athletes. Acta Diabetol 2003;40 Suppl 1:S142-4.

5. Oppliger RA, Utter AC, Scott JR, Dick RW, Klossner D. NCAA rule change improves weight loss among national championship wrestlers. Med Sci Sports Exerc 2006;38(5):963-70.

6. World Karate Federation. New Kata and Kumite Rules. WKF: France. 2018; Available from: https://www.wkf.net/pdf/WKFCompetitionRules2018.pdf[2019 Aug 10].

7. Roschel H, Batista M, Monteiro R, Bertuzzi RC, Barroso R, Loturco I, et al. Association between neuromuscular tests and kumite performance on the Brazilian Karate National Team. J Sports Sci Med 2009;8(CSSI3):20-4. 
8. Layton C. Reaction+ movement-time and sidedness in shotokan karate students. Percept Mot Skills 1993;76(3 Pt 1):765-6.

9. Fontani G, Lodi L, Felici A, Migliorini S, Corradeschi F. Attention in athletes of high and low experience engaged in different open skill sports. Percept Mot Skills 2006;102(3):791-805.

10. Chaabene H, Hachana Y, Franchini E, Mkaouer B, Chamari K. Physical and physiological profile of elite karate athletes. Sports Med 2012;42(10):829-43.

11. Giampietro M, Pujia A, Bertini I. Anthropometric features and body composition of young athletes practicing karate at a high and medium competitive level. Acta Diabetol 2003;40(1):s145-s8.

12. Beneke R, Beyer T, Jachner C, Erasmus J, Hütler M. Energetics of karate kumite. Eur J Appl Physiol 2004;92(4-5):518-23.

13. Doria C, Veicsteinas A, Limonta E, Maggioni MA, Aschieri P, Eusebi F, et al. Energetics of karate (kata and kumite techniques) in top-level athletes. Eur J Appl Physiol 2009;107(5):603-10.

14. Nunan D. Development of a sports specific aerobic capacity test for karate-a pilot study. J Sports Sci Med 2006;5(CSSI):47-53.

15. Chaabène H, Hachana Y, Franchini E, Mkaouer B, Montassar M, Chamari K. Reliability and construct validity of the karate-specific aerobic test. J Strength Cond Res 2012;26(12):3454-60.

16. Tabben M, Coquart J, Chaabène H, Franchini E, Chamari K, Tourny C. Validity and reliability of new karate-specific aerobic test for karatekas. Int J Sports Physiol Perform 2014;9(6):953-8.

17. Stewart A, Marfell-Jones MJ, Olds T, De Ridder H. International standards for anthropometric assessment. Lower Hutt, New Zealand : International Society for the Advancement of Kinanthropometry; 2011.

18. Krugh M, Langaker MD. Dual Energy Xray Absorptiometry (DEXA). StatPearls Publishing; United States. 2018; Available from: https://www.ncbi.nlm.nih.gov/ books/NBK519042/ [2019 Aug 09].

19. Mcardle WD, Katch FI, Katch VL. Fisiologia do exercício: nutrição, energia e desempenho humano. 7a ed. Rio Janeiro: Guanabara Koogan; 2011.

20. Chaabène H, Hachana Y, Attia A, Mkaouer B, Chaabouni S, Chamari K. Relative and Absolute Reliability of Karate Specific Aerobic Test (Ksat) in Experienced Male Athletes. Biol Sport 2012;29(3):211-215.

21. Chaabene H. Karate kumite: how to optimize performance. Physical Determinants of Karate Kumite. OMICS; United States. 2015; Available from: https://www. researchgate.net/publication/291693868_Karate_kumite_how_to_optimize_performance [2019 Aug 06].

22. Imamura H, Yoshimura Y, Uchida K, Nishimura S, Nakazawa AT. Maximal oxygen uptake, body composition and strength of highly competitive and novice karate practitioners. Appl Human Sci 1998;17(5):215-8.

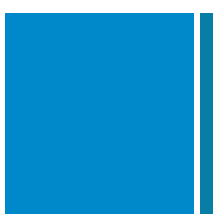

Corresponding author

Daniel da Rocha Queiroz

Arnóbio Marques street, 310

Zip postal: 50100-130

Recife, PE, Brazil

E-mail: efdanielrocha@live.com 